\title{
Mengimplementasikan Pelayanan Yesus Dalam Konteks Misi Masa Kini Menurut Injil Sinoptik
}

\author{
Kalis Stevanus \\ 1) Dosen Sekolah Tinggi Teologi Tawangmangu \\ *) Penulis korespondensi: kalisstevanus91@ gmail.com
}

Received: 19 Dec 2018 / Revised: 25 Dec 2018 / Accepted: 28 Dec 2018

\begin{abstract}
Abstrak
Gereja sebagai bagian dari masyarakat juga terpanggil untuk terlibat dalam upaya mengatasi permasalahan yang sedang terjadi di sekitarnya. Makalah ini bertujuan untuk memperlihatkan bahwa pelayanan kristiani secara komprehensif yaitu pelayanan holistik adalah sangat relevan dan dibutuhkan sebagai jawaban untuk mewujudkan Injil Yesus Kristus menjadi realitas dan sekaligus dapat mengentaskan persoalan atau kondisi masyarakat di mana gereja berada. Pelayanan holistik adalah sebuah paham akan peranan gereja dalam lingkup sosial, yakni pengontekstualisasian Injil Yesus Kristus pada masalah konkret yang terjadi di sekitar gereja. Pelayanan holistic sebagai upaya untuk merealisasikan pengajaran Alkitab ke dalam praksis, yang tentunya hal ini berlaku di tengah-tengah kondisi dan situasi masalah konkret di sekitar gereja.

Berdasarkan kajian biblika khususnya pemberitaan Injil Sinoptik mengenai pelayanan Tuhan Yesus, tampak sangat jelas bahwa Ia tidak memisahkan (dualisme) antara Pemberitaan Injil dan kepedulian social. Pelayanan-Nya tidak hanya focus pada Pemberitaan Injil semata, yaitu penobatan seseorang menjadi murid-Nya untuk memperoleh keselamatan jiwa, namun bersifat holistik, yakni juga memerhatikan kebutuhan sosial. Seyogyianya pelayanan gereja masa kini pun juga holistic (utuh; menyeluruh) seperti yang telah dilakukan oleh Tuhan Yesus.
\end{abstract}

Kata kunci: Pelayanan Tuhan Yesus, pelayanan holistic, Injil sinoptik, gereja, masa kini 


\begin{abstract}
The Church as part of the community is also called to be involved in efforts to overcome the problems that are happening around it. This paper aims to show that Christian service in a comprehensive manner that is holistic ministry is very relevant and needed as an answer to realizing the gospel of Jesus Christ into reality and at the same time can alleviate the problem or condition of the community in which the church is located. Holistic service is an understanding of the role of the church in the social sphere, namely contextualizing the gospel of Jesus Christ on concrete problems that occur around the church. Holistic service as an effort to realize the teaching of the Bible into praxis, which certainly applies in the midst of conditions and situations of concrete problems around the church.

Based on biblical studies in particular the preaching of the Synoptic Gospels concerning the ministry of the Lord Jesus, it seems very clear that He did not separate (dualism) between Gospel Preaching and social concern. His ministry does not only focus on preaching the Gospel alone, namely the coronation of a person to be his disciple to obtain soul salvation, but it is holistic, which is also concerned with social needs. Today's church services should also be holistic as a whole that was done by the Lord Jesus.
\end{abstract}

Keywords: Lord Jesus' ministry, holistic ministry, synoptic gospel, church, today

\title{
Pendahuluan
}

Alkitab memaparkan dengan jelas bahwa semua orang percaya diberi mandat untuk melaksanakan misi Pekabaran Injil kepada semua bangsa. Mandat ini sering disebut sebagai Amanat Agung (Mat.28:18-20; Mrk.16:15; Luk.24:47). Sesudah kebangkitan, Tuhan Yesus menjanjikan kepada murid-murid-Nya bahwa mereka akan menjadi saksi (Kis.1:8) dan memerintahkan mereka untuk melaksanakan misi Pekabaran Injil kepada semua bangsa. Semua orang percaya tanpa kecuali dipanggil untuk menaati perintah missioner tersebut.

Menurut B.E. Drewes, sebenarnya juga sebelum Amanat Agung di dalam Matius pasal 28, telah ada kontak antara Tuhan Yesus dan bangsabangsa lain. Juga sebelum kebangkitan-Nya, menjadi jelas bahwa maksud tujuan Allah meliputi segala bangsa. Hal ini sesuai dengan Perjanjian 
Lama, di mana Abraham dipilih untuk menjadi berkat bagi segala bangsa (Kej.12:1-3). Dalam kehidupan Tuhan Yesus, perspektif ini nyata, di mana titik tolak pelayanan Tuhan Yesus disebut kota Kapernaum, yang terletak di "Galilea, wilayah bangsa-bangsa lain" (Mat.4:13-16). Dikatakan oleh Drewes, bahwa memang Galilea adalah merupakan daerah Yahudi, tetapi bukan pusat daerah Yahudi seperti daerah Yudea dengan kota Yerusalem. Galilea dekat dengan daerah bangsa-bansga yang bukan Yahudi. Kapernaum dan Galilea digambarkan oleh Matius sebagai tempat yang terbuka bagi manusia dari bangsa-bangsa yang bukan Israel. Dan sesudah kebangkitan-Nya, terbukalah jalan bagi segala bangsa untuk menjadi bagian dari umat Allah (Mat.28:18-20). Dengan demikian terpenuhilah pengharapan akan keselamatan bagi bangsa-bangsa seperti yang dinubuatkan oleh para nabi (Yes.2:2-3; band. Mi.4:1-2; Zak.8:22-23). ${ }^{1}$

Tentang misi Tuhan Yesus kepada dunia bangsa-bangsa lain juga ditegaskan oleh Samuel Benyamin Hakh, sebagai berikut:

"Yesus, menurut ketiga Injil Sinoptik, memiliki perhatian yang cukup besar terhadap misi kepada semua bangsa. Hal ini nyata dari laporan ketiga Injil ini bahwa Yesus tidak hanya melaksanakan misiNya atau memberitakan Kerajaan Allah kepada bangsa-Nya sendiri, yaitu bangsa Israel tetapi Ia juga melintasi batas bangsa-Nya pergi ke daerah yang bukan Yahudi untuk memberitakan Injil dan melakukan mujizat." 2

Dengan demikian dapat dikatakan bahwa pelayanan Tuhan Yesus menurut Injil Sinoptik, Ia memiliki perhatian yang cukup besar terhadap misi kepada dunia bangsa-bangsa bukan Yahudi. Perhatian itu Ia wujudkan tidak hanya dengan memberitakan Injil Kerajaan Allah dan melakukan mujizat bagi orang-orang bukan Yahudi yang datang kepada-Nya, tetapi lebih dari itu Ia menyeberangi daerah Palestina dan memasuki daerah bangsa kafir untuk memberitakan Injil Kerajaan Allah.

Mandat untuk memberitakan Injil kepada semua bangsa seantero dunia adalah "bukti" dan sekaligus "fakta" keuniversalan dari Injil Yesus Kristus. Dalam perintah-Nya jelas, bahwa wilayah yang harus dicapai dengan Pekabaran Injil adalah seluruh "kosmos"-tempat tinggal untuk manusia. Tanggung jawab kitalah memberitakan Injil kepada segala

\footnotetext{
${ }^{1}$ B.E. Drewes, 2001. Satu Injil Tiga Pekabar (Jakarta: BPK Gunung Mulia), 248-249

${ }^{2}$ Samuel Benyamin Hakh, 2008. Pemberitaan Tentang Yesus Menurut Injil Sinoptik (Bandung: Jurnal Info Media), 58
} 
makhluk, yaitu manusia. ${ }^{3}$ Gereja yakni seluruh umat Tuhan dipanggil untuk meneruskan perintah misioner Pekabaran Injil sampai tuntas mencapai seluruh "kosmos", sampai kepada kedatangan Tuhan Yesus yang kedua kali. Inilah fondasi bagi misi Kristen sedunia.

Dalam perutusannya gereja diutus oleh Tuhan Yesus Kristus ke dalam dunia menjadi terang dan garam dunia. Dalam interaksinya dengan dunia di mana ia hidup diperhadapkan dengan berbagai masalah sosial, ekonomi, politik, pendidikan, kesehatan dan berbagai masalah sosial lainnya yang juga menjadi pergumulan masyarakat secara umum. Dalam kondisi inilah, pada satu sisi orang gereja dipanggil untuk menjadi terang dan garam atau menghadirkan shalom di dunia yang penuh dengan penderitaan dan tantangan yang juga menerpa kehidupannya.

Gereja tidak boleh melalaikan peran aktifnya di bidang social sehingga memberikan pengaruhnya yang positif (terang dan garam) dalam kehidupan sosial di masyarakat. Terkadang gereja atau orang Kristen secara salah menganggap Pekabaran Injil hanya berkenaan dengan kerohanian personal dan tidak berkenaan dengan kehidupan sekular, sehingga tidak merasa berkewajiban untuk memikirkan tanggungjawab sosialnya. Sejatinya Pekabaran Injil terintegrasi dalam seluruh aspek kehidupan, termasuk bidang sosial. Itu sebabnya gereja tidak bisa tidak memerhatikan dan mengusahakan kehidupan sosial yang lebih baik bagi masyarakat di mana ia berada.

Pelayanan holistic merupakan dimensi pelayanan gereja yang perlu dilakukan. Menurut Will Metzger bahwa pelayanan holistic sebenarnya berangkat dari suatu kesadaran bahwa pelayanan Kristiani kepada orangorang yang terhilang harus juga memerhatikan aspek-aspek kebutuhan jasmaniah orang-orang yang dilayani. Dan ini adalah sebuah kesadaran yang sangat baik. $^{4}$

Sebab itu, penulis tertarik untuk mengangkat topik pembahasan tulisan ini, yaitu: "Mengimplementasikan Pelayanan Yesus Dalam Konteks Misi Masa Kini Menurut Injil Sinoptik." Menurut hemat penulis, segala pergumulan jemaat maupun masyarakat, tidak cukup diatasi hanya dengan

\footnotetext{
${ }^{3}$ Kalis Stevanus, 2017. Benarkah Injil Untuk Semua Orang (Yogyakarta: Diandra), 3

${ }^{4}$ Will Metzger, Tell the Truth: The Whole to the Whole Person by the Whole People (Surabaya: Momentum, 2005), hlm.319
} 
didoakan. ${ }^{5}$ Membantu mencari jalan keluar dari permasalahan yang mereka hadapi dibutuhkan tindakan lain selain doa, yaitu pelayanan holistic yang akan membawa sejahtera dalam kehidupan individu maupun masyarakat, sehingga terwujudlah peradaban shalom.

\section{Pengertian Pelayanan Holistik}

Kata "pelayanan" dalam Kamus Bahasa Indonesia, adalah perihal atau cara melayani. ${ }^{6}$ Sedangkan kata "holistik" akar katanya berasal dari bahasa Yunani holos yang artinya semua, keseluruhan, total. Jadi, pelayanan holistik adalah cara melayani secara menyeluruh. Itu adalah pengertian secara umum.

Sedangkan pengertian pelayanan holistik yang dikaitkan dengan kegiatan Pemberitaan Injil menurut Herlianto, pelayanan holistic adalah pelayanan yang mencakup Pemberitaan Injil baik secara verbal maupun secara perbuatan dan ditujukan untuk menjangkau manusia seutuhnya, yaitu manusia yang terdiri dari tubuh, jiwa dan roh, dan manusia yang mempunyai kaitan-kaitan sosial, budaya, ekonomi, hukum dan politik dengan lingkungannya. ${ }^{7}$ Yakob Tomatala menyatakan bahwa hakikat atau esensi pelayanan holistik di mana dapat dijelaskan sebagai "satu yang menyeluruh" yang memiliki kesatuan integral dengan aspek-aspek lengkap yang utuh. Pemberitaan Injil menyentuh aspek pelayanan dasar pada empat dimensi pelayanan yang holistik yaitu: Persekutuan (koinoneo), Pelayanan (diakoneo), Kesaksian (martureo) dan Pemberitaan (kerigma/kerusso). ${ }^{8}$ Pendapat tersebut juga diungkapkan oleh J.C. Hoekendijk sebagaimana dikutip oleh Arie de Kuiper di dalam bukunya "Misiologia", dijelaskan bahwa pelayanan holistik itu meliputi unsur-unsur pelayanan, yaitu: Koinonia (persekutuan), Martyria (kesaksian), dan Diakonia (pelayanan sosial), merupakan hal yang mutlak menggarisi Pekabaran Injil dan mendatangkan syalom (damai sejahtera, keselamatan) yang dijanjikan oleh Tuhan. ${ }^{9}$

Berdasarkan pemahaman di atas, maka dapat disimpulkan bahwa pelayanan holistik adalah pelayanan yang dilakukan secara utuh, yakni

\footnotetext{
5 Jika dikatakan "tidak cukup dengan doa" penulis tidak bermaksud meremehkan kuasa doa. Doa adalah mutlak perlu dan sangat penting sebagai penyangga dari iman dan pelayanan Kristen. Tetapi doa tidak boleh menggantikan tanggung jawab kita untuk bekerja.

${ }^{6}$ KBBI Online

${ }^{7}$ Herlianto, 1998. Pelayanan Perkotaan (Bandung: Yabina), 123

${ }^{8}$ Yakob Tomatala, 2003. Teologi Misi (Jakarta: YT Leadership Foundation), 61

${ }^{9}$ Arie de Kuiper, 2003. Misiologia (Jakarta: BPK Gunung Mulia), 74
} 
Pemberitaan Injil yang merangkumi segala bidang kehidupan manusia baik secara rohani maupun jasmaninya (seperti sosial, pendidikan, kesehatan, ekonomi, dan sebagainya). Tidak seharusnya ada pertentangan antara pelayanan diakonia (kebutuhan fisik maupun psikis) dan marturia (kebutuhan rohani atau keselamatan). Oleh karena itu, dalam pelayanan Kristiani tidak dikenal dualisme atau pemisahan antara kebutuhan individual dan sosial manusia. Pelayanan holistik berupaya untuk memulihkan keseimbangan dan keserasian antara keduanya. Diakonia adalah wujud dari kesaksian Kristiani (marturia).

\section{Dasar Teologis pelayanan holistic adalah pelayanan Yesus Kristus sendiri}

Risnawaty Sinulingga menyatakan bahwa penyampaian berita keselamatan itu (Pemberitaan Injil) yang dilakukan oleh Yesus Kristus jelas memperlihatkan sifatnya yang menyeluruh (holistic), tidak pernah hanya berbentuk pemberitaan firman tetapi juga kesaksian hidup dan pelayanan kasih, tidak hanya bagi keselamatan yang batiniah tetapi juga berkaitan dengan kebutuhan jasmaniah dalam kehidupan sehari-hari. ${ }^{10}$

Tuhan Yesus menyampaikan Kabar Baik ${ }^{11}$ kepada orang-orang miskin, memberitakan pembebasan bagi orang tawanan, menyembuhkan orang-orang sakit, membebaskan orang-orang tertindas (Luk 4:18-19). Ia juga memberikan makan kepada mereka yang lapar (Mrk.8:1-10; Mat.15:32-39). Yesus juga memperhatikan jiwa manusia. Yesus membebaskan dan memulihkan jiwa dari orang gila di Gerasa yang dipengaruhi oleh kuasa setan (Mat. 8:28-34; Mrk.5:1-18; Luk. 8:26-37). Juga dipaparkan di Matius 25:31-46, di mana Tuhan Yesus mengidentikkan diri-Nya sebagai orang lapar, orang yang sakit, haus, telanjang, terpenjara dan orang asing. Tuhan Yesus juga menegaskan bahwa apa yang kita perbuat kepada orang susah (memberi makan, memberi minum, memberi

\footnotetext{
${ }^{10}$ Risnawaty Sinulingga "Suatu Tinjauan Teologis Tentang Misi” Jurnal Teologi Tabernakel, Edisi XVIII, 2007: 41

${ }^{11}$ Istilah Kabar Baik identic dengan Injil. Samuel Benyamin Hakh, menjelaskan kata "Injil" (Yun: euangelion), diterjemahkan dari kata Ibrani besorah artinya pahala, hadiah, upah yang diberikan kepada seseorang yang membawa kemenangan (2 Sam.4:10). Kata besorah juga dapat berarti kabar baik atau berita sukacita (2 Sam.18:20,22). Lihat, Samuel Benyamin Hakh, hlm.27
} 
tumpangan, memberi pakaian, mendoakan dan mengobati, mengunjungi orang dalam penjara) sama seperti melakukannya kepada diri-Nya.

Joel B. Green mengatakan bahwa Kerajaan Allah telah datang melalui kehadiran dan karya Tuhan Yesus yang menyentuh seluruh aspek kehidupan manusia. Solidaritas-Nya didemonstrasikan melalui tindakan nyata. Ketika Ia berinteraksi dengan orang-orang non Yahudi, orang-orang Samaria, "orang-orang berdosa," para penderita kusta, dan yang lainnya. Yesus menerobos pagar-pagar pemisah yang selama ini telah terbangun selama beberapa waktu di dalam kehidupan Yahudi. Ketika Tuhan Yesus menunjuk seorang serdadu non Yahudi sebagai teladan iman (Luk.7:1-10), ketika Ia mempersilakan wanita menjadi pengikut-Nya (Luk.8:1-3), ketika Ia memanggil pemungut cukai menjadi murid-Nya (Mrk.2:13-14), Tuhan Yesus telah mendemonstrasikan bahwa Kabar Baik tentang keselamatan Allah tidak mengenal batasan. ${ }^{12}$ Ia sangat peduli dengan mereka yang tiada mendapat tempat dalam masyarakat, misalnya karena faktor status sosialnya (pemungut cukai, perempuan pelacur), atau karena faktor ekonomi (nelayan), atau karena faktor jasmaninya (orang lumpuh, orang buta, orang kusta), atau karena faktor etnis (orang-orang Samaria).

Tuhan Yesus sendiri telah memberi contoh konkrit dari apa yang telah dilakukannya tampak nyata pelayanan-Nya sangat holistik, yaitu meliputi seluruh aspek kehidupan manusia. Pelayanan-Nya bukan hanya dalam rangka penobatan yang membuat orang lain menjadi pengikut Kristus untuk keselamatan jiwanya, tetapi juga berbentuk pelayanan kasih sehingga orang buta melihat, orang lumpuh berjalan, orang buta melihat dan kepada orang miskin diberitakan Kabar Baik (Mat. 11: 4-5). Sepanjang hidup dan pelayanan-Nya, Tuhan Yesus telah menunjukkan kepada kita bahwa Ia adalah sebagai "model pelayan holistik". Yesus sangat solider dengan orang-orang yang berada di sekitar-Nya, salah satunya adalah dengan memenuhi kebutuhan mereka secara utuh.

Berdasarkan paparan di dalam Injil Sinoptik, dapat disimpulkan bahwa pelayanan Tuhan Yesus sangat komprehensif, atau menyeluruh karena yang menjadi sasarannya bukan hanya hal rohani saja tetapi juga peduli terhadap isu-isu social untuk menyatakan kasih Allah kepada mereka yang memerlukan. Pelayanan holistic adalah suatu pemikiran teologis yang alkitabiah dan merupakan suatu pendekatan baru yang radikal terhadap tugas teologi di mana titik tolaknya mengacu pada persoalan konkret di

\footnotetext{
${ }^{12}$ Joel B. Green, 2005. Memahami Injil-injil dan Kisah Para Rasul (Jakarta: Persekutuan Pembaca Alkitab), 178
} 
masyarakat di mana gereja berada dan di mana Allah juga hadir di dalamnya. Kemudian pihak gereja melibatkan diri dan berpihak pada masyarakat yang tak berdaya atau yang membutuhkan uluran tangan. Pelayanan holistic merupakan refleksi gereja sebagai suatu komunitas terhadap suatu persoalan social masyarakat di sekitarnya. Refleksi teologis harus sesuai dengan tantangan sosial dan masalah-masalah kontemporer di mana gereja berada (eksis), misalnya seperti rasisme dan kemiskinan dan lain sebagainya harus diperlakukan sebagai masalah teologis.

\section{Tujuan Pelayanan Holistik}

Penulis merasa perlu mengemukakan di sini tentang pentingnya gereja memiliki pemahaman yang benar tentang pelayanan holistic dalam kaitannya dengan Amanat Agung atau Pekabaran Injil. Terkadang dijumpai pelayanan holistik dijadikan "alat" untuk mengkristenkan orang. Seharusnya niat pemberitaan Injil didasarkan pada kerinduan atau kasih agar mereka yang terhilang dalam dosa beroleh keselamatan melalui iman kepada Tuhan Yesus. Inilah motif yang benar untuk kegiatan pelayanan kristiani apa pun bentuknya. Pelayanan holistic tidak hanya berusaha menyelamatkan jiwa, tetapi juga menolong mereka untuk mulai merasakan berkat-berkat Kerajaan Allah dalam kehidupan mereka sekarang ini.

Ada yang berpendapat bahwa gereja seharusnya hanya mengerjakan Pekabaran Injil, yaitu perihal keselamatan kekal (bidang rohani) saja, bukan pada isu-isu social. Ada juga yang berpandangan bahwa perbuatan belas kasih (kepedulian sosial) sebagai sarana bagi tujuan Pekabaran Injil. Di sisi lain juga, ada yang berpandangan bahwa mengerjakan isu-isu sosial itu berarti identic dengan menyebarluaskan atau proklamasi Injil.

Memang, mengerjakan isu-isu sosial dapat memimpin orang untuk mendengarkan pesan dari Injil Yesus Kristus, tapi menganggap perbuatan belas kasih (kepedulian sosial) sebagai identik dengan proklamasi Injil adalah kerancuan yang fatal. Sejatinya mengerjakan isu-isu sosial bukanlah Injil tapi buah dari Injil. Selama ini gereja atau orang Kristen banyak memfokuskan pelayanannya sebatas hal-hal rohani saja, belum masuk kepada bentuk-bentuk pelayanan yang menolong orang susah. Padahal pelayanan gereja harus menyeluruh atau holistic seperti yang telah dilakukan oleh Tuhan Yesus. 
Nasihat nabi Yeremia tentang mengusahakan damai sejahtera seperti tertulis pada pasal 29 ayat 7 demikian: "Usahakanlah kesejahteraan (shalom) kota ke mana kamu Aku buang, dan berdoalah untuk kota itu kepada TUHAN, sebab kesejahteraannya adalah kesejahteraanmu". Menurut Zinzendorf Dachi bahwa konsep shalom dalam Yeremia 29 merupakan bagian penting dalam kehidupan Israel sebagai suatu bangsa. Dalam suratnya kepada orang-orang yang ada di pembuangan, Yeremia menekankan bahwa damai sejahtera atau kesejahteraan dapat mereka alami atau nikmati meskipun mereka tidak tinggal di tanah perjanjian. Kata "Usahakanlah" (ITB), "Bekerjalah" (BIS). Kata ini diterjemahkan dengan "Bahkan usahakanlah." Kata kerja imperatif dalam ayat ini merupakan lanjutan dari kata kerja imperatif dalam ayat 6. Perintah untuk menghadirkan shalom merupakan suatu keharusan bagi bangsa Israel di pembuangan. Upaya menghadirkan shalom di Babel, tidak lepas dari sikap serta bagaimana cara mereka hidup. Mereka harus tinggal dengan mendirikan rumah untuk mereka diami dan membuat kebun untuk mereka tanami sehingga menghasilkan sesuatu untuk dimakan. Dengan mengolah alam dan memelihara lingkungan di mana mereka berdiam, mereka dapat menikmati damai sejahtera sekalipun di tempat penghukuman. ${ }^{13}$

Menghadirkan shalom merupakan tanggung jawab orang Israel di pembuangan. Nabi Yeremia menegaskan bahwa meskipun mereka ada di Babel, tidak menjadi halangan bagi mereka untuk membangun relasi dengan Allah, dengan sesama, dengan diri sendiri dan dengan alam. Melalui kerja keras mereka dalam mengelola tanah, mereka dapat menikmati hasil dari tanah yang mereka olah. Tanggung jawab mengelola tanah dengan berkebun dan menggunakan hasil alam untuk membangun tempat tinggal, merupakan sikap yang harus mereka tunjukkan sebagai umat Allah di tengah-tengah bangsa lain.

Perintah menghadirkan shalom, bukan hanya umat Israel tetapi itu juga merupakan tugas Kristiani yang diberikan Allah kepada gereja-Nya dengan kelahiran Yesus Kristus, yaitu menjadi shalom bagi manusia di bumi. Tugas menghadirkan shalom di bumi bukan hanya dislogankan, tetapi harus diusahakan. Pelayanan Kristiani tidak hanya soal pemulihan hubungan kembali antara manusia dengan Allah, namun juga memerhatikan isu-isu social guna menghasilkan shalom di antara manusia.

\footnotetext{
${ }^{13}$ Zinzendorf Dachi, "Menghadirkan Shalom Berdasarkan Yeremia 29:4-7" Illuminate Jurnal Teologi dan Pendidikan Kristiani Vol 1, No 1, Juni 2018:45
} 
Tuhan Yesus disebut Raja shalom (Yes 9:5). Pada kelahiran-Nya malaikat mengatakan, "Damai sejahtera (shalom) di antara manusia" (Luk 2:14). Dengan kehadiran Tuhan Yesus, maka dimulailah suatu zaman baru di mana Allah bersedia merestorasi kembali keberadaan manusia. Andar Ismail menjabarkan arti kata shalom dengan contoh-contoh berikut ini: Jika bangsa dan negara dalam persatuan, tak terpecah dan tak terkotak, maka dikatakan bahwa bangsa dan negara berada dalam shalom. Di sini shalom berarti keutuhan. Jika dua orang atau kelompok berdamai kembali setelah beberapa waktu terputus atau renggang, maka dikatakan antara kedua orang atau kelompok itu terdapat shalom. Di sini shalom berarti keselarasan. Jika panen berhasil dan tiap orang tercukupi kebutuhan hidupnya, maka disebutkanlah rakyat hidup dalam shalom Di sini shalom berarti damai sejahtera atau makmur atau berkat. Jika suatu perjalanan telah kita lewati dengan baik, tanpa gangguan, maka dikatakan kita telah mendapat shalom. Di sini shalom berarti selamat. ${ }^{14}$

Jadi arti kata "shalom" sendiri di dalam Alkitab memang sangat holistic yaitu keselamatan, damai sejahtera, keamanan, kesatuan dan berkat (makmur). Jadi Injil tidak hanya merupakan kabar keselamatan rohani, tetapi juga meliputi seluruh aspek kehidupan manusia.

Billy Graham ketika ditanyai tentang hubungan antara kegiatan sosial dan Pekabaran Injil, ia mengatakan bahwa Pekabaran Injil sangat erat hubungannya dengan kegiatan sosial. Gereja harus turut merasa terbeban atas kebutuhan manusia. Sebab dengan penuh kasih, Allah memerhatikan setiap aspek penderitaan manusia. Beberapa gerakan sosial terbesar yang terjadi dalam sejarah dunia ini merupakan hasil/buah dari Pekabaran Injil. Ke negara mana saja utusan Injil pergi memberitakan kasih Kristus yang menebus umat manusia, di situ pula dibangun rumah-rumah sakit, sekolahsekolah, panti-panti asuhan, dan terdapat beratus-ratus bentuk pelayanan lainnya. $^{15}$

Ditambahkan oleh John Stott bahwa aksi sosial bukan sebagai sarana untuk Pekabaran Injil tetapi sebagai "perwujudan" dari Pekabaran Injil yang sedang diberitakan. Dengan demikian, aksi sosial membuat pesan Injil menjadi sangat terlihat. Seperti yang diungkapkan oleh National

\footnotetext{
${ }^{14}$ Andar Ismail, 1999. Selamat Natal (Jakarta: BPK Gunung Mulia), 14-15

${ }^{15}$ Billy Graham, 199. Beritakan Inil (Yogyakarta: Andi2), 41
} 
Evangelical Anglican Congres di Keele pada tahun 1976, yang mengatakan Penginjilan dan pelayanan yang penuh kasih harus ada bersama-sama misi Allah. ${ }^{16}$ Jadi, baik Pekabaran Injil maupun tindakan social, keduanya merupakan ekspresi dari kasih agape. Sebab, tanpa kasih agape itu, kegiatan pelayanan Kristiani kita tidak murni dan tidak sesuai kehendak-Nya. Seperti teladan Tuhan Yesus, dimana segala kegiatan pelayanannya didasarkan pada kasih, yaitu tergerak oleh belas kasihan seperti yang dipaparkan di dalam Injil Sinoptik (Mat.9:36; Mrk.6:34; Luk.7:13). ${ }^{17}$

Penulis tidak perlu ragu untuk menyetujui pandangan Billy Graham maupun John Stott mengenai pelayanan holistic karena ada contoh (dasar teologis) yang kuat yaitu pelayanan Yesus sendiri. Perkataan dan perbuatanNya saling terkait, perkataan-Nya menafsirkan perbuatan-Nya dan perbuatan-Nya mewujudkan perkataan-Nya. Dia tidak hanya memberitakan Injil Kerajaan Allah. Dia mempertunjukkan "tanda-tanda Kerajaan Allah" secara terlihat. Jika orang-orang tidak mau percaya perkataan-Nya, kata Yesus, maka biarlah mereka percaya kepada-Nya "karena pekerjaanpekerjaan itu sendiri" (Yoh.14:11)

Tuhan Yesus memberikan mandat Amanat Agung kepada muridmurid-Nya, "Karena itu pergilah, jadikanlah semua bangsa murid-Ku dan baptislah mereka dalam nama Bapa dan Anak dan Roh Kudus, dan ajarlah mereka melakukan segala sesuatu yang telah Kuperintahkan kepadamu" (Mat. 28:19-20). Namun pada kesempatan lain juga, Tuhan Yesus memerintahkan manusia untuk saling mengasihi. Injil Sinoptik mencatat, bahwa Tuhan Yesus mengutip Perjanjian Lama. Imamat 19:18,"Kasihilah sesamamu manusia seperti dirimu sendiri" (band. Mat.22:39; Mrk.12:31; Luk.10: 27). Mengasihi sesama adalah hukum utama yang kedua, setelah perintah untuk mengasihi Tuhan, Allah dengan segenap hati, segenap jiwamu dan dengan segenap akal budi.

Jelas di sini ada dua perintah Tuhan Yesus, yaitu Hukum Utama dan Amanat Agung. Apa hubungan dari keduanya? Keduanya saling terkait (integral). Amanat Agung (Pemberitaan Injil) tidak terpisah dengan hukum utama. Amanat Agung (Pemberitaan Injil) tidak menggantikan hukum utama itu. Gereja harus menaati perintah missioner (Amanat Agung) tersebut untuk memberitakan Injil Kerajaan Allah kepada segala suku

\footnotetext{
${ }^{16}$ John Stott, 2013. Murid Radikal yang Mengubah Dunia (Surabaya: Perkantas Jawa Timur), 39

${ }^{17}$ Kalis Stevanus, Benarkah Injil untuk Seтиа Orang, 149
} 
bangsa. Namun, itu bukanlah sebagai satu-satunya perintah yang Tuhan Yesus berikan kepada gereja-Nya.

Pernyataan Perjanjian Lausanne menegaskan bahwa Pekabaran Injil dan keterlibatan secara sosial merupakan bagian dari tugas gereja. Karena keduanya merupakan wujud yang harus ada bagi pengajaran gereja tentang Allah dan manusia, di mana kasih kita bagi sesama manusia dan ketaatan kita kepada Tuhan Yesus. ${ }^{18}$

Bagaimana kita bisa mengklaim bahwa kita mengasihinya jika kita mengetahui mereka susah, lapar, sakit, dan sebagainya, namun tidak berusaha menolongnya. Sebaliknya, jika kita sungguh-sungguh mengasihi sesama kita maka kita tidak boleh berhenti hanya dengan memberitakan Injil. Sebab sesama kita bukanlah jiwa tanpa tubuh, sehingga kitapun harus mengasihi dan berusaha memerhatikan secara menyeluruh (holistic) baik jiwanya dan juga tubuhnya. Kasih terhadap sesama, dapat ditunjukkan dengan menjawab kebutuhan secara jasmaniah orang-orang yang berada di sekitar kita.

Oleh karena itu, dapat disimpulkan bahwa pelayanan holistic ini bertujuan untuk mendatangkan kebaikan (Kabar Baik) bagi manusia seutuhnya (1 Tes.5:23). Penulis setuju dengan pernyataan Petrus Octavianus bahwa pelayanan holistic tidak hanya berusaha menyelamatkan jiwa, tetapi juga menolong mereka untuk mulai merasakan berkat-berkat Kerajaan Allah dalam kehidupan mereka sekarang ini. Jadi, pelayanan sosial di dalamnya termasuk pengembangan masyarakat itu juga merupakan bagian dari misi Kristen karena gereja diutus untuk melakukan hal-hal tersebut. Inilah misi yang sesungguhnya. ${ }^{19}$

Penting gereja masa kini mengkaji ulang pelayanannya dengan mengacu apa yang Tuhan Yesus ajarkan dan lakukan pada masa hidup-Nya, sehingga mampu menjawab persoalan-persoalan yang dihadapi dalam konteksnya di mana gereja berada. Gereja tidak boleh melalaikan tugas dan panggilannya untuk membangun masyarakat. Benar apa yang dikatakan Kuyper bahwa ketika seorang Kristen hidup berdasarkan prinsip ajaran

\footnotetext{
${ }^{18}$ John Stott, 2013. Murid Radikal yang Mengubah Dunia, 31

${ }^{19}$ Petrus Octavianus, 1985. Identitas Kebudayaan Asia dalam Terang Firman Allah (Batu: YPPII), 33-34
} 
Kitab Suci, ia tidak bisa tidak memerhatikan dan mengusahakan kehidupan sosial yang lebih baik bagi masyarakat di mana ia ditempatkan. ${ }^{20}$

Gereja hidup dan berkembang bukan untuk dirinya sendiri tetapi untuk membangun Kerajaan Allah yang mendatangkan damai sejahtera, keadilan, dan kebenaran di bumi ini. Gereja yang adalah lembaga yang dibangun oleh Kristus dan dilengkapi kuasa-Nya untuk menghadirkan Kerajaan Allah di bumi menjadi harapan dan sarana di mana Allah bekerja bagi dan melalui umat-Nya untuk memberkati masyarakat. Gereja selalu bergumul dengan dunia di mana ia diutus. Gereja bergumul dengan teks dan konteksnya, sehingga gereja tetap menjalankan fungsinya menjadi garam dan terang bagi dunia.

\section{Kesimpulan}

Membicarakan kepedulian sosial dan misi Pekabaran Injil dalam konteks pelayanan Kristiani, pada saat ini sangat mendesak. Misi kristiani Pekabaran Injil sering dipisahkan dari kepedulian sosial, atau sebaliknya kepedulian sosial dipisahkan dari misi Pekabaran Injil. Hubungan keduanya ibarat dua sisi mata uang, yang tidak dapat terpisahkan. Tendensi penekanan pada satu sisi, akan mengakibatkan ketidakseimbangan dalam pelayanan. Pekabaran Injil yang memisahkan kepedulian sosial akan mengeluarkan intervensi Allah dari sejarah.

Pemahaman gereja sekarang tentang misi Kristen dalam konteks masa kini harus dikaitkan dengan pemahaman atas Matius 5-7, Matius 22:37-40 dan Matius 25:31-46 yang berisi kepedulian Allah terhadap manusia. Pemahaman seperti ini akan membawa berita yang lebih holistic. Dengan memahami pengutusan atau misi Pekabaran Injil melalui pemahaman di atas, kita akan menjumpai pesan: bahwa keselamatan yang diberikan oleh Tuhan adalah keselamatan yang universal, yang mencakup seluruh manusia ciptaan Tuhan. Dengan pemahaman ini hendak ditegaskan bahwa nuansa yang dibangun oleh Yesus Kristus dalam kehidupan adalah nuansa kebersamaan antara setiap individu tanpa membatasi berbagai perbedaan. Dengan demikian, proses misi Pekabaran Injil yang harus dilakukan adalah kepedulian Tuhan kepada manusia adalah kepedulian yang tidak membedakan dan adil. Demikian pula ketika kita (gereja) berbicara tentang keselamatan, maka yang diberikan oleh Tuhan bukanlah keselamatan parsial (keselamatan dalam bidang rohani saja dan ditujukan

${ }^{20}$ Abraham Kuyper, 2004. Iman Kristen dan Problema Sosial (Surabaya: Momentum), x 
hanya untuk orang Kristen), melainkan holistik (mencakup roh, jiwa dan tubuh) sekaligus universal. Keselamatan adalah hak miliki semua orang, tanpa membedakan ras, golongan ataupun kondisi social.

Sangat jelas diungkapkan di dalam Injil Sinoptik di atas bahwa pelayanan yang dilakukan Tuhan Yesus sangat holistic. Ia tidak hanya peduli terhadap masalah keselamatan kekal, tapi juga memperdulikan isuisu social yang di sekitarnya. Pelayanan holistik yaitu melayani masyarakat secara seutuhnya adalah sebagai wujud ketaatan pada amanat Ilahi ganda yang Tuhan berikan, yaitu memberitakan Injil dan perintah untuk mengasihi sesama seperti diri sendiri. Gereja perlu melihat kebutuhan manusia dari dua sisi, yaitu kebutuhan rohani dan jasmani. Iman itu harus diwujudnyatakan dalam perbuatan yang riil pula, seperti mengulurkan tangan bagi mereka yang memerlukan. Pelayanan holistic bukan sebagai jembatan untuk mengkristenkan orang atau untuk meredam aksi protes masyarakat terhadap kehadiran gereja, tetapi untuk mewujudkan Injil Yesus Kristus dalam realitas. Pelayanan holistik adalah alkitabiah dan sangat relevan merupakan aplikasi yang dibutuhkan untuk menghadirkan Kerajaan Allah atau shalom di mana gereja berada.

\section{Kepustakaan}

Drewes, B.E. 2001. Satu Injil Tiga Pekabar. Jakarta: BPK Gunung Mulia Dachi, Zinzendorf. "Menghadirkan Shalom Berdasarkan Yeremia 29:4-7" Illuminate Jurnal Teologi dan Pendidikan Kristiani Vol 1, No 1, Juni 2018

Green, Joel B. 2005. Memahami Injil-injil dan Kisah Para Rasul. Jakarta: Persekutuan Pembaca Alkitab

Graham, Bily. 1992. Beritakan Injil. Yogyakarta: Andi

Hakh, Samuel Benyamin. 2008. Pemberitaan Tentang Yesus Menurut Injil

Sinoptik. Bandung: Jurnal Info Media

Herlianto, 1998. Pelayanan Perkotaan. Bandung: Yabina

Ismail, Andar. 1999. Selamat Natal. Jakarta: BPK Gunung Mulia

Kuiper, Arie de. 2003. Misiologia. Jakarta: BPK Gunung Mulia

Kuiper, Arie de. 2004. Iman Kristen dan Problema Sosial. Surabaya: MomentumMetzger, Will. 2005. Tell the Truth: The Whole to the Whole

Person by the Whole People. Surabaya: Momentum

Stevanus, Kalis. 2017. Benarkah Injil Untuk Semua Orang. Yogyakarta: 
Diandra

Stevanus, Kalis. 2018. Lihatlah Sang Juruselamat Dunia. Yogyakarta:

Diandra

Sinulingga, Risnawaty. "Suatu Tinjauan Teologis Tentang Misi" Jurnal Teologi Tabernakel, Edisi XVIII, 2007

Stott, John. 2013. Murid Radikal yang Mengubah Dunia. Surabaya:

Perkantas Jawa Timur

Octavianus, Petrus. 1985. Identitas Kebudayaan Asia dalam Terang Firman Allah. Batu: YPPII

Tomatala, Yakob. 2003. Teologi Misi. Jakarta: YT Leadership Foundation 